\title{
Impact of Rishikesh-Karanprayag railway line on the agroecosystem of Maletha village of Garhwal Himalaya
}

\author{
Sharma, R.凶, Bhandari, B.S., Kumari, S., Falswal, A.
}

Received: 05.12.2020

Revised: 10.03.2021

Accepted: 20.03.2021

\begin{abstract}
Uttarakhand is a newly incepted state, geographically and culturally distinct from the plains and is the prime destination of tourists not only from India but also from different parts of the globe. Railways in Uttarakhand will certainly play a crucial role in the development of the state. Ministry of Railways of India has launched and initiated a project to connect the Char dhams of the state which will surely prove a landmark in the developmental feat of the state but development and modernization at the cost of disturbing the ecosystem in general and agricultural ecosystem in particular will create an imbalance in the livelihood of the people who by and large depend on agriculture economy. The present study was carried out in an agriculturally rich medium sized village of Uttarakhand. The survey reveal that climatic and geographical conditions of the village are suitable for the cultivation of large number of vegetables, fruits, cereals, millets, pulses and fodder plants supporting the livelihood of the natives. Land acquisition would have a negative impact on the socio-economic condition of the farmers as well as on the traditional crop diversity of the area as the railway project covers most of the fertile land. Thus, for reducing the havoc in the lives of the villagers government should provide land as an exchange as most of the population is agriculture dependent and at the same time degradation should be viewed with long-term vision.
\end{abstract}

Key words: Agriculture, Development, Diversity, Ecosystem, Garhwal Himalaya, Livelihood

\section{Introduction}

The Himalayan region is an ecologically important mountainous terrain as it provides a wide range of forest ecosystem services for many mountain communities (Rasul, 2014; Badola, et al., 2015; Chakraborty et al., 2016a) and where flora and fauna vary extensively with climate diversity from one region to the other. This region is often associated with social and economic benefits for most rural households (Sandhu and Sandhu, 2014; Charley et al., 2016; Hoy et al., 2016). Uttarakhand state is located in Northern India and is known as the source of legendary river Ganga and Yamuna. The geographical area of the state is $53,483 \mathrm{~km}^{2}$ with the elevation ranging from 210 to $7817 \mathrm{~m}$ asl and constitute $1.63 \%$ of the country's total area. Geographically, the state is located between $28^{\circ} 43$ ' $\mathrm{N}-31^{\circ} 28^{\prime} \mathrm{N}$ latitude and $77^{\circ} 34^{\prime} \mathrm{E}-81^{\circ} 03 \mathrm{E}$ longitude. The Uttarakhand region is geographically and culturally different from the plains- $65 \%$ of the area

\section{Author's Address}

Ecology Laboratory, Department of Botany and Microbiology HNB Garhwal University, Srinagar Garhwal, 246174, Uttarakhnad, India

E-mail.: ruchikasharma0505@gmail.com is covered with forests and the mountain area is under-developed. The Garhwal Himalaya of Uttarakhand spreading over 30,000 sq. km., rich in forest wealth, meadows, marshes, swamps, etc. with their characteristic ecosystems. Geoclimatic variations in these himalayan regions help to generate diverse vegetation and high plant species diversity (Chawla et al., 2008). People are mostly dependent on forests to cater their daily needs like fuel, fodder, timber, medicines, food, fertilizer, etc. Uttarakhand in general and hilly regions in particular are the prime destination of tourists not only from the different parts of India but from different parts of the globe too. This is because of holy shrines, natural beauty, panoramic views, and the cultural heritage from time immemorial. Uttarakhand blessed with scenic beauty and religious shrines attract lakhs of tourists and pilgrims every year. Although every part of the state is well connected with road network but by connecting the Char dhams (Kedarnath, Badrinath, Gangotri and Yamunotri) with railline, this state can potentially provide an easy and safe way of travelling. 
The $125 \mathrm{~km}$ Rishikesh-Karanprayag rail line comprises of 13 stations, 16 tunnels and 35 bridges. Out of $125 \mathrm{~km}, 120 \mathrm{~km}$ of the railline track is under tunnel project. According to Railway Ministry, "Railways have decided to use $100 \%$ electric traction on Rishikesh-Karanprayag route which will ensure pollution free journey speeding through the picturesque landscape of the state.

In this study attempts have been made to assess the impact analysis of developmental activities like railway tracks in the fragile mountain ecosystem in general and agricultural land in particular. Although the project will surely prove a landmark in the development feat of the state and will simultaneously boost the economy but forest officials are worried for this project since preliminary survey work has begun and includes a $3 \mathrm{~km}$ stretch through Rishikesh forest range and could affect 550 animals including elephants and leopards (Sharma, 2014).

Railways in Uttarakhand will certainly play a crucial role in the development of newly incepted state. Though development and destruction are the two important issues in the fragile mountain ecosystem but if development proceeds, there are other negative impacts which should not be ignored at any cost. As the undergoing project is being constructing on the acquired agricultural land from the villagers, therefore, the present study is carried out with the aim to know the possible impacts of the railline construction on the lives of nativeswho depend on their agricultural land for livelihood.

\section{Materials and Methods}

The study was carried out in a small village 'Maletha' of Devprayag block of district Tehri Garhwal of Uttarakhand Himalaya. The village is settled next to National Highway 58, on right bank of Alaknanda River at a vertical distance of $400 \mathrm{~m}$. It is about $25 \mathrm{~km}$ upstream from Devprayag where Alaknanda from left and Bhagirathi from right side unite to form the Ganga River. It is located $25 \mathrm{~km}$ towards east from district head quarter Tehri and $74 \mathrm{~km}$ from state capital Dehradun. Village is situated at an altitude between $480-600 \mathrm{~m}$ asl.

The climate of Maletha is tropical with hot summers and severe winters. The average annual rainfall is $705 \mathrm{~mm}$ with mean atmospheric temperature ranges from 22 to $40^{\circ} \mathrm{C}$. The soil type is alluvial which is fertile and suitable for agriculture. Most of the land is irrigated. The village is surrounded by mixed deciduous forest, comprising Khair (Acacia catechu), Axlewood (Anogeissus latifolia), Indian Elm (Holoptelia integrifolia) and Kadamb (Adina cordifolia) as dominant tree species.

Maletha, situated in Uttarakhand, where one of the 13 railway station will be constructed and be named after the great Madho Singh Bhandari. Maletha village owns most of the fertile farmland which once barren and made suitable for agriculture with the painstakingly efforts by creating irrigational channel from Chandrabagha river to the village by the brave of Maletha, Madho Singh Bhandari. Even today the village carry the legacy of this great person and as a result of his hardwork Maletha has the lowest migration rate in comparison with other adjacent villages of the state. In Maletha village, railway yard construction is in progress where multiple railway tracks will be structured. 2 tunnels are going to be constructed between Maletha and Srinagar of $8.194 \mathrm{~km}$ length. Main tunnel is of 4.07 $\mathrm{km}$ with the second escape tunnel of $4.13 \mathrm{~km}$. Detailed field survey was carried out in order to collect general information about the study area. Quantitative data collection has been done with the help of questionnaires prepared in a semi-structured format comprised of both open and closed ended questions. Interviews were conducted in order to collect maximum information with the elder member of the family and with women particularly for specific information. The questions covered the general information regarding age, length of residency, educational status, household income and source of income, land own, livestock, major crops grown, their dependency on fields and the land given to the government for railway line project. The information collected is helpful in understanding their livelihood and agriculture dependency and views about the RishikeshKaranprayag project. The major information was collected from the women of the village because women play a major role in housekeeping as well as in field works. Women collect fodder from forests for their cattle and grow crops and harvest them. Information was also collected from shopkeepers of the village and people working in the fields of Maletha village for cross-checking. 


\section{Results and Discussion}

The results of the study carried out in Maletha village reveal some interesting points. The proposed railway line project covers most of the land of the villagers, which is fertile and only source of income for number of natives. Total numbers of households in the village are 33 and 30 households are affected by this project. According to the Directorate of Census Operations (2011), in the agricultural labourer's category, Tehri and Devaprayag blocks of the Garhwal Himalayan region have the highest percentage of 1.30 and 1.15 respectively. Maletha village of Devprayag block holds a significant number of agricultural land and labourers. The source of irrigation in the village is through canals which are well established.

Maletha village is rich in terms of ground diversity. Also large number of species of vegetables, fruits, millets, and cereals (Table 1) are cultivated here which add as a source of income generation for number of natives. Maletha is also rich in fodder plants which form the backbone of cattle rearing and an important part in the livelihood of the villagers. Cheena (Panicum miliaceum) crop is grown only in Maletha village, not in other parts of Uttarakhand. Its cultivation period is from April to June. It is also called common millet or broomcorn millet. Cheena crop is also one of among the world's most ancient domesticated crops (Lu et al., 2009). Cheena millet grain used for human consumption and livestock feed. Also Cheena is a short-season crop which grows very well in poor soil and requires minimum water for their growth (Baltensperger 2002; Nesbitt, 2005). The people of Maletha are mostly dependent on agriculture. The major crops grown in Maletha are wheat, rice and pulses (soyabean, urad, frenchbean, etc.). Jhangora and Mandua are also famous food crops of Maletha. Some of the households were totally dependent on their fields because they do not have any other source of income other than agriculture. Agriculture dependent people grow crops like cereals, millets, pulses, vegetables, fruits, etc. to run their households. Most of the people are not happy with this rail line project because they are all agriculture dependent people and their land is to be vanished by this project.

According to Zaman (1990), cash compensation is mostly beneficial for some interest groups (big landlords) whereas common people, small scale farmers and landless people need "land-for-land" approach as land is their key to reestablishment and contributes to cultural activity. The study carried out also revealed that there is a big nursery in the area which was established about 22 years ago and harbours approximately 14 lakhs mulberry plants. Also, in addition every species of citrus plant, fodder plant, all local vegetables, and grafted varieties of mango are also cultivated there. Beside this, apiculture and sericulture practices have also been performed there. This large scale project provides employment to the number of people. But in the proposed rail line project, approximately $90 \%$ of the nursery land is under constructed area. This will leave the workers in a jobless way and hugely affect the economy provided by the nursery. Land contributes as main source of livelihood in any agricultural economy (Parwez and Sen, 2016). India, even today is a land of villages and nearly $70 \%$ population residing in the rural areas and involved in agricultural production (Ministry of Statistics and Programme Implementation, 2019). Access to land is one of the most important assets for rural people and in many cases; it is valuable for their livelihoods (Ellis, 2000). Acquisition of land will impact local's life and livelihood and lead to shortage of productive land.

Acquisition of land and land transfer for businesses leads to large-scale unemployment and displacement and raises many questions about the goals and process of establishing special economic zones (Parvez and Sen, 2016). Large-scale investments in the rural areas sometime badly affect natives as they have to shift from their main land and improper consultation and inadequate compensation worse their economic condition (The Oakland Institute, 2011a). Also in the regions, where majority of people are dependent on agriculture for their livelihood, acquisition of their fertile land without providing them ample opportunities in other economic sectors enhance poverty, unemployment and food insecurity (Oxfam, 2011). Sometime situations such as loss of fertile land, livelihood, poor income generation put pressures on urban migration (UN DESA, 2010). Migration is already a burning issue in Uttarakhand state as dozens of village in the state are now ghost villages as thousands of people already settled down in urban areas like Dehradun and Delhi in 
Table 1: Major crops grown in the Maletha village

\begin{tabular}{|c|c|c|}
\hline Vernacular Name & Botanical Name & Family \\
\hline \multicolumn{3}{|c|}{ MILLETS } \\
\hline Cheena & Panicummiliaceum & Poaceae \\
\hline Mandua & Eleusinecoracana & Poaceae \\
\hline Jhangora & Echinochloaesculenta & Poaceae \\
\hline Rye & Secalecereal & Poaceae \\
\hline Jowar & Sorghum vulgare & Poaceae \\
\hline \multicolumn{3}{|c|}{ CEREALS } \\
\hline Wheat & Triticumaestivum & Poaceae \\
\hline Rice & Oryzasativa & Poaceae \\
\hline \multicolumn{3}{|c|}{ VEGETABLES } \\
\hline Tomato & Solanumlycopersicum & Solanaceae \\
\hline Onion & Allium cepa & Amyryllidaceae \\
\hline Spinach & Spinaciaoleracea & Amaranthaceae \\
\hline French bean & Phaseolus vulgaris & Fabaceae \\
\hline Radish & Raphanussativus & Brassicaceae \\
\hline Lady-finger & Abelmoschusesculentus & Malvaceae \\
\hline Coriander & Coriandrumsativum & Apiaceae \\
\hline Potato & Solanumtuberosum & Solanaceae \\
\hline Curry tree & Murrayakoenigii & Rutaceae \\
\hline Torii & Luffaacutangula & Cucurbitaceae \\
\hline Bottle guard & Lagenariasiceraria & Cucurbitaceae \\
\hline Snake guard & Trichosanthescucumerina & Cucurbitaceae \\
\hline Pumpkin & Cucurbitapepo & Cucurbitaceae \\
\hline Cucumber & Cucumissativus & Cucurbitaceae \\
\hline Mustard & Brassica campestris & Brassicaceae \\
\hline Black eyed pea & Vignaunguiculata & Fabaceae \\
\hline Urad & Vignamungo & Fabaceae \\
\hline Soyabean & Glycine max & Fabaceae \\
\hline Capsicum & Capsicum spp. & Solanaceae \\
\hline \multicolumn{3}{|c|}{ FRUITS } \\
\hline Mulberry & Morus spp. & Moraceae \\
\hline Mango & Mangiferaindica & Anacardiaceae \\
\hline Lemon & Citrus limon & Rutaceae \\
\hline Orange & Citrus sinensis & Rutaceae \\
\hline \multicolumn{3}{|c|}{ FODDER } \\
\hline Kachnar & Bauhinia variegate & Fabaceae \\
\hline Charee & Sorghum vulgare & Poaceae \\
\hline
\end{tabular}

search of job and other better facilities. Agricultural acquisition for development projects as an land acquisition for urbanization (ALAFU) is one inescapable cause of suffering to the affected of the most popular and cheap option in the people, leading to marginalization, deprivation, and developing countries (Schneider, 2012; Azadi et al., social exclusion (Cernia, 2000; Council for Social 2011), but it results in the disordered life and Development, 2008; De Wet, 2001; Fernandes, livelihoods of natives of the affected areas as they 1998, 2005, 2009; Mahapatra, 1999; Penz et al., depended on agricultural land, and have low 2011; Sharma, 2010; World Bank, 2004).

education and working skills causing low adaptive Development and modernization is necessary but capacity during social-economic change (ILO, not at the cost of disturbing the ecosystem and by 2011; Nguyen et al., 2016). There are other studies creating an imbalance in the livelihood of the too across the world which has substantiated land- people. Although the natives of Maletha village feel 
blessed that their village is going to be modernized but loss of vegetation and livelihood is a matter of concern. Farming generates less but sustainable income to support livelihood of the native on long term basis. But without providing training and skills to manage compensation, farmers may end up with no land to farm. Land acquisition would have a negative effect on the socio-economic condition of the farmers as well as on the traditional crop diversity of the affected area. Some responders will also lose their shops and hotels and that will be a big blow to their economic life. Pollution (soil pollution, noise pollution) is also a big issue which cannot be neglected and cutting of trees of adjacent areas even worsen the condition.

\section{Conclusion}

Agricultural land is an asset for the natives of rural areas of developing countries as it provides an economic and financial security to them).Indian Railways are the single largest user of land and rural developmental projects are one of the key reasons behind this. The study concluded that acquisition of agricultural land is the main driver which will impact the livelihood of natives of the area and causes a decline in their source of income. Although people need not to shift to new places due

\section{References}

Azadi, H., Ho, P. and Hasfiati, L., 2011. Agricultural land conversion drivers: A comparison between less developed, developing and developed countries. Land Degradation Development, 22:596-604.

Badola, R., Hussain, S. A., Dobriyal, P. and Barthwal, S., 2015. Assessing the effectiveness of policies in sustaining and promoting ecosystem services in the Indian Himalayas. International Journal of Biodiversity Science, Ecosystem Services \& Management, 11:216-224.

Baltensperger, D.D., 2002. Progress with proso, pearl and other millets In J. Janick and A. Whipkey (eds.), Trends in new crops and new uses. Alexandria (VA): American Society for Horticultural Science Press. pp: 1-9.

Chawla, A., Rajkumar, S., Singh, K. N., Lal, B., Thukral, A.K. and Singh, R.D., 2008. Plant species diversity along an altitudinal gradient of Bhabha Valley in Western Himalaya. Journal of Mountain Science, 5(2):157-177.

Cernia, M. M., 2000. Risks, safeguards and reconstruction: a model for population displacement and resettlement. Economic and Political Weekly, 35(41):3659-3678. to rail line construction as the constructing project is somewhat distant from the residential locality but it leave the majority of villagers landless as it occupies a large portion of their fertile land. Displacing people from their agriculture, environmental losses, poor compensation at undervalued market price, etc. have often become the main recipe for growing dispute between the authorities and the affected people. Land for land policy should have been adopted by the government as it is a more manageable way which adds stability in their lives as land is the primary determinant of their livelihoods. Also, cash compensation is for the land owners, and not for the labourers, so it is a negative setback for the livelihood of wage workers also. However, the undergoing railway project surely boosts the tourism but negative implications are much more. Although this study has focused only on few important aspects like acquisition of agricultural land and its impact on livelihood of natives, but likewise, there are myriad of issues which are yet to be examined from environmental point of view, food security, job security, etc. which should be keep in focus for future studies. However, the crucial point that emerged from the study requires heedful importance to avoid further chaos in the lives of the villagers.

Council for Social Development, 2008. Indian social development report: Development and displacement. New Delhi: Oxford University Press.

Chakraborty, A., R., Shukla, K., Sachdeva, P., Roy, S. and Joshi P. K., 2016a. The climate change conundrum and the Himalayan forests: The way forward into the future. Proceedings of the National Academy of Sciences, India Section B: Biological Sciences.

Charlery, L., Nielsen, M. R., Meilby, H and Smith-Hall, C., 2016. Effects of new roads on environmental resource use in the Central Himalaya. Sustainability, 8:363.

De Wet, C., 2001. Economic development and population displacement: Can everybody win? Economic \& Political Weekly, 36(50):4637-4646.

Ellis, F., 2000. Rural Livelihoods and Diversity in Developing Countries. Oxford University Press: Oxford, UK.

Fernandes, W., 1998. Land acquisition (amendment) bill, 1998: Rights of project-affected people ignored. Economic and Political Weekly, 33(42- 43):2703-2706. 


\section{Sharma et al.}

Fernandes, W., 2005. Rehabilitation as a right: Where is the policy? Social Action. 55(2):123-137.

Fernandes, W., 2009. India's half century search for a resettlement policy and the right to livelihood. In R. Modi (eds.), Beyond relocation: The imperative of sustainable resettlement. New Delhi: Sage. pp: 102-126.

Hoy, A., Katel, O., Thapa, P., Dendup, N. and Matschullat, J., 2016. Climatic changes and their impact on socioeconomic sectors in the Bhutan Himalayas: An implementation strategy. Regional Environmental Change, 16: 1401-1415.

ILO, 2011. Research Report on Rural Labour and Employment in Vietnam. International Labour Organization: Hanoi, Vietnam.

Lu, H., Zhang, H., Liu, K., Wu, N., Li, Y., Zhou, K., Ye, M., Zhang, T., Zhang, H., Yang, X., Shen, L., Xu, D., and Li, Q., 2009. Earliest Domestication of common millet (Panicum miliaceum) in East Asia extended to 10,000 years ago. Proceedings of the National Academy of Sciences U S A., 106(18):7367-7372.

Mahapatra, L.K., 1999. Resettlement, impoverishment and reconstruction in India: Development for the deprived. New Delhi: Vikas Publishing House.

Ministry of Statistics and Programme Implementation, 2019. Sector-wise contribution of GDP India.

Nesbitt M. Grains, 2005. In: Prance G, Nesbitt M, (eds.), Cultural History of Plants. London: Routledge, pp: 45-60.

Nguyen, T.H.T., Tran, V.T., Bui, Q.T., Man, Q.H. and de Vries Walter, T., 2016. Socio-economic effects of agricultural land conversion for urban development: Case study of Hanoi, Vietnam. Land Use Policy, 54:583-592.

Oxfam, 2011. The growing scandal surrounding the new wave of investments in land. Land and Power. Oxfam Briefing Paper, pp: 151.

Parwez, S. and Sen, V., 2016. Special economic zone, land acquisition, and impact on rural India. Emerging Economy Studies, 2:223-239.
Penz, P., Drydyk, J., and Bose, P. S., 2011. Displacement by development: Ethics, rights and responsibilities. New York: Cambridge University Press.

Rasul G., 2014. Food, water and energy security in South Asia: A nexus perspective from the Hindu Kush Himalayan region. Environmental Science \& Policy, 39:35-48.

Sandhu, H. and Sandhu, S., 2014. Linking ecosystem services with the constituents of human well-being for poverty alleviation in eastern Himalayas. Ecological Economics, 107:65-75.

Sharma, R.N., 2010. Changing facets of involuntary displacement and resettlement in India. Social Change, 40(1):503-524.

Sharma, S, 2014. Trains to chug through Rishikesh forest In Role of Rail systems in preserving Biosphere, Environment, Forests, Ecology, Biodiversity and Wildlife, Water resources, Pollution control, relevant statutory policies, the NGT and MoEF. Times Of India.

Schneider, A., 2012. Monitoring land cover change in urban and peri-urban areas using dense time stacks of Landsat satellite data and a data mining approach. Remote Sensing Environment, 124:689-704.

The Oakland Institute, 2011a. Agrisol Energy and Pharos Global Agriculture Fund's Land Deal in Tanzania. Understanding Land Investment Deals in Africa. Land Deal Brief.

UN DESA, 2010. Foreign land purchases for agriculture: What impact on sustainable development? Sustainable development innovation briefs. United Nations Department for Economic and Social Affairs. 8.

World Bank, 2004. Involuntary resettlement sourcebook: Planning and implementation of development projects. Washington D.C.: Author.

Zaman, M. Q., 1990. Land acquisition and compensation in involuntary resettlement. Land, Resources and Environment, 14:4. http://sandrp.wordpress.com $(21 / 07 / 2015)$ 